\title{
Tongue papillae morphology of brown-throated sloth Bradypus variegatus (SCHINZ, 1825)
}

[Morfologia das papilas linguais de preguiça comum Bradypus variegatus (SCHINZ, 1825)]

\author{
D.M. Martins ${ }^{1}$, L.L. Pinheiro ${ }^{1}$, V.C. Ferreira ${ }^{1}$, A.M. Costa ${ }^{2}$, A.R. Lima $^{1}$, R.E.G. Ricci ${ }^{3}$, \\ M.A. Miglino ${ }^{3}$, E. Branco ${ }^{1 *}$ \\ ${ }^{1}$ Universidade Federal Rural da Amazônia - UFRA - Belém, PA \\ ${ }^{2}$ Museu Emílio Goeldi - Belém, PA \\ ${ }^{3}$ Universidade de São Paulo - São Paulo, SP
}

\begin{abstract}
The Bradypus variegatus inhabits the forests of South America and feeds from leaves, branches and sprouts from different plants. Due to its diet and the lack of literature on the morphological aspect of Xenarthras, five Bradypus variegatus tongues from animals which died from natural causes were evaluated, and they came from Pará State Museum Emílio Goeldi and were donated to the Laboratory of Animal Morphological Research (LaPMA) from UFRA, for revealing the different types of papillae and epithelial-connective tissue. Macroscopically, the tongues presented elongated shape, rounded apex, body, root, median sulcus in the root's apex, and two vallate papillae. The mucous membrane of the tongue revealed a keratinized stratified pavement epithelium, while the ventral surface of the tongue was thin and smooth, not provided with any type of papillae. However, the dorsal surface of the tongue was irregular with the presence of three types of papillae: filiform, fungiform and vallate papillae. The filiform papillae found were of a simple type, presenting a rounded base, irregularly distributed with a larger concentration and development on the tongue's apex and body. The fungiform papilla showed a practically smooth surface with irregular format, with the presence of gustatory pores; these were found all over the dorsal surface, with larger concentration at the rostral part of the apex. Only two vallate papillae were observed disposed in the root of the tongue, surrounded by a deep groove, and revealing several taste buds. The tongues from Bradypus variegatus presented gustatory papillae similar to the ones described for other Xenarthras species and wild mammals.
\end{abstract}

Keywords: morphology, lingual papillae, Bradypus variegatus

\section{RESUMO}

A Bradypus variegatus habita florestas da América do Sul e alimenta-se de folhas, ramos e brotos de várias plantas. Em decorrência de sua dieta, bem como da escassez de literatura sobre aspectos morfológicos dos Xenarthras, avaliaram-se cinco línguas de Bradypus variegatus, que foram a óbito por causas naturais, provenientes do Museu Paraense Emílio Goeldi e doados ao Laboratório de Pesquisa Morfológica Animal (LaPMA) da UFRA, a fim de se elucidarem os diferentes tipos de papilas e a interface epitélio-tecido conjuntivo. Macroscopicamente, as línguas apresentaram formato alongado, ápice arredondado, corpo, raiz, sulco mediano do ápice à raiz e duas papilas valadas. A mucosa da língua revelou epitélio de revestimento pavimentoso estratificado queratinizado, enquanto a face ventral era delgada e lisa, desprovida de qualquer tipo de papila. Já a face dorsal apresentou-se irregular, com a presença de três tipos papilares: papilas filiformes, fungiformes e valadas. As papilas filiformes encontradas eram do tipo simples, com base circular, distribuídas irregularmente, com maior concentração e desenvolvimento no ápice e no corpo da língua. A papila fungiforme mostrou-se com superfície praticamente lisa e de formato irregular, com a presença de poros gustativos. Estas foram encontradas por toda a superfície dorsal, com maior concentração na parte rostral do ápice. Foram

Recebido em 26 de outubro de 2012

Aceito em 25 de junho de 2014

*Autor para correspondência (corresponding author)

E-mail: ebranco.ufra@gmail.com 
observadas apenas duas papilas valadas, dispostas na região da raiz da língua, com corpo rodeado por sulcos profundos e vários botões gustativos. As línguas de Bradypus variegatus apresentaram papilas linguais similares às descritas para outras espécies de Xenarthras e mamíferos selvagens.

Palavras-chave: morfologia, papila lingual, Bradypus variegatus

\section{INTRODUCTION}

The Xenarthra order, also known as Edentata, includes sloths, armadillos and anteaters (Cartelle, 1994). The sloths' species differ by the number of nails in the thoracic members. The animals from the Bradypus species present three nails, and particularly the brown-throated sloth of Brazil were described as Bradypus variegatus (Schinz, 1825) (Wetzel and Kock, 1973).

The Bradypus variegatus, also known as brown-throated sloth, is currently extinct from Argentina, its occurrence in Paraguay is uncertain, and in Brazil, it is absent in the states of Santa Catarina and Rio Grande do Sul (Aguiar, 2004). It is a tree-living species, feeding from leaves, branches and sprouts from different plants, but mainly the ones from the Moraceae family (Chiarello et al., 2004). However, the most consumed part of the plant is the leaves, representing $94 \%$ of the items consumed, and the ingestion of young leaves and sprouts can increase if they are more abundant in the forest (Queiroz, 1995).

Studies on the particularities and peculiarities of the anatomical and morfofunctional characters of the brown-throated sloth are important, as well as knowing its feeding habits and the range of food available. Therefore, the present work aims to show the anatomical structures of the tongue, characterizing them according to their shape, spatial distribution and verifying the histological and ultra-structural details of the different papillae and surfaces of epithelial-connective tissue interface. Thus, new projects for basic and applied works can be suggested, also contributing with subsidizes for future investigations and preservation of the species.

\section{MATERIALS AND METHODS}

The entire collection procedure and the manipulation of the material evaluated are in compliance with the Biodiversity Authorization and Information System - SISBIO, $\mathrm{n}^{\circ}$ 23401-1.
For the present study, five specimens of brownthroated sloth (Bradypus variegatus, Schinz, 1825) were used, three young females and two young males, from 3 to 7 weeks of life, which died from natural causes, coming from Pará State Museum Emílio Goeldi located in Belém - PA, donated to the Laboratory of Animal Morphological Research (LaPMA), from Federal Rural University of Amazon - UFRA.

All the animals were cryopreserved and they were slowly thawed in running water, with subsequent removal of the tongue out of the oral cavity through temporomandibular disarticulation, under the use of basic dissection material, and kept submerged in flasks containing formaldehyde solution buffered at $10 \%$.

The material was processed in the Histology Laboratory from the Surgery Department, the sector of Domestic and Wild Animals Anatomy from Veterinary and Animal Science School from USP, being measured and divided in apex, body and root, fixed by immersion in paraformaldehyde solution buffered at $10 \%$ for light microscopy and fixed in a modified solution of Karnovsky containing 2.5\% of glutaraldehyde and $2 \%$ of paraformaldehyde according to Watanabe and Yamada (1983), for scanning electron microscopy swap.

The material destined to the light microscopy was cut in $5 \mu \mathrm{m}$ thickness, in Leica RM 2065 microtome, later assembled in glass sheets and colored with Hematoxylin-Eosin, Masson Trichrome and histochemical reaction method PAS (periodic acid + Schiff reactive) .

The sheets were observed and photographed in Leica DME binocular light microscope, and Olympus BX50 photomicroscope with digital image capture.

The samples for scanning microscopy were later fixed in osmium tretroxide at $1 \%$ for $1 \mathrm{~h}$ at $4^{\circ} \mathrm{C}$, and washed with distilled water in the sequence for the time period of 3 hours and immersed in 
water solution containing $1 \%$ of tannic acid, at room temperature for 1 hour, followed by growing dehydration in a series of alcohols $(60 \%$ to absolute) and dried in Balzers CPD-030 or Balzers CPP-020 critical point, using liquid CO2. The samples were assembled in metal stubs and covered with an EMITECH k 550 golden layer and analyzed with the LEO 435VP scanning electron microscope.

\section{RESULTS}

The Bradypus variegatus tongues macroscopically analyzed presented an elongated format, rounded apex, body and root, median sulcus of the apex and root and two vallate papillae (Figure 1). The mucous membrane of the tongue presented keratinized stratified pavement epithelium, while the ventral face of the tongue was thin and smooth, not provided with any type of papilla. However, the dorsal surface of the tongue was irregular with the presence of three types of papillae: filiform, fungiform and vallate papillae (Figure 3A). The filiform papillae found were from a simple type, presenting a rounded base, irregularly distributed with larger concentration and development at the apex and body of the tongue (Figure 2A and Figure 3C). The fungiform papilla showed a practically smooth surface with irregular format, with the presence of gustatory pores; these were found all over the dorsal surface, with a larger concentration $\mathrm{n}$ the rostral part of the apex (Figure 2B and Figure 3B).

Only two vallate papillae were observed, disposed in the root of the tongue (Figure 3D). Macroscopically, these papillae had the body surrounded by a deep groove (Figure 3D), and microscopically, several taste buds were observed, located all over the surface of the tongue (Figure 2C and D).

\section{DISCUSSION}

The morphology of the tongue of the animals can suffer variations according to the taxonomy, habitat, behavior and diet (Okada and Schraufnagel, 2005). According to findings by Jackowiak and Godynicki (2004), the presence, distribution and structure of the taste buds are correlated to the feeding habits of the animal, and it can vary and suffer adaptations (Pastor et al., 2008).

Doran and Baggett (1971) concluded that the tongue of mammals can be divided in two functional categories, each one with a clear morphological correlation. Type I, which has a "spatula" format and presents an intra-oral function during mastication, and the type II, which presents a "cigar-shape" format, mainly characterized by the extra-oral function for on the capture of food, as it occurs in some monotremes. In the present study, the Bradypus variegatus' tongues analyzed present morphology compatible with type I, in other words, an elongated body and a rounded apex.

In a similar way, the three-toed sloth (Bradypus torquatus) presented the rounded apex of the tongue (Benetti et al., 2009), different from the dwarf armadillo (Zaedyus pichiy), another Xenarthra, which revealed an elongated triangular shape and a pointed apex (Ciuccio et al., 2008).

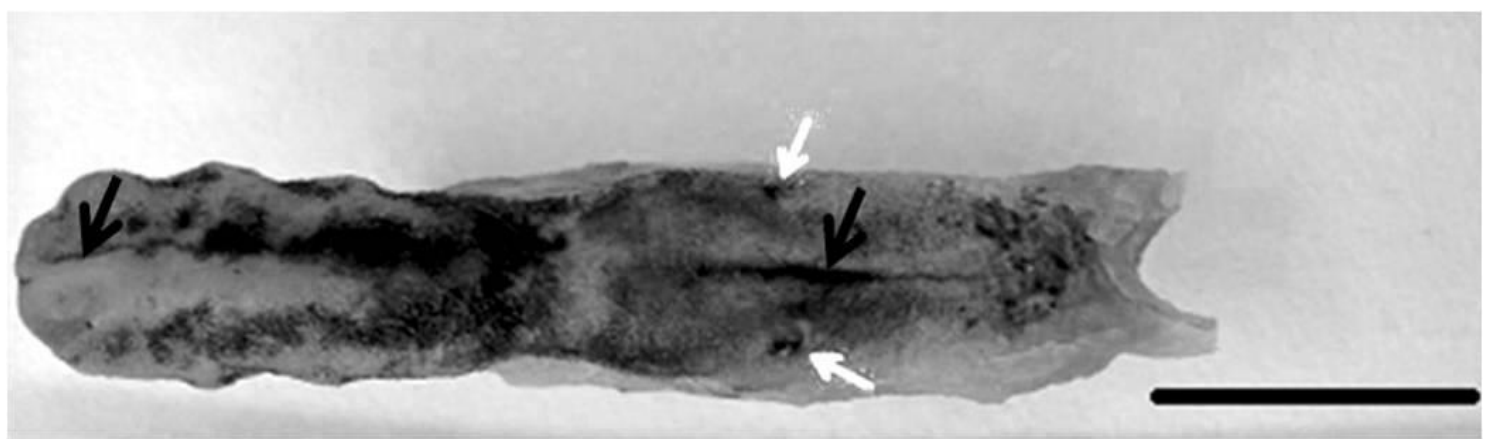

Figure 1. Photomacrografy in dorsal view of Bradypus variegatus tongue. White arrows show the vallate papillae; the black arrow shows the median furrow. Scale bar: $1 \mathrm{~cm}$. 


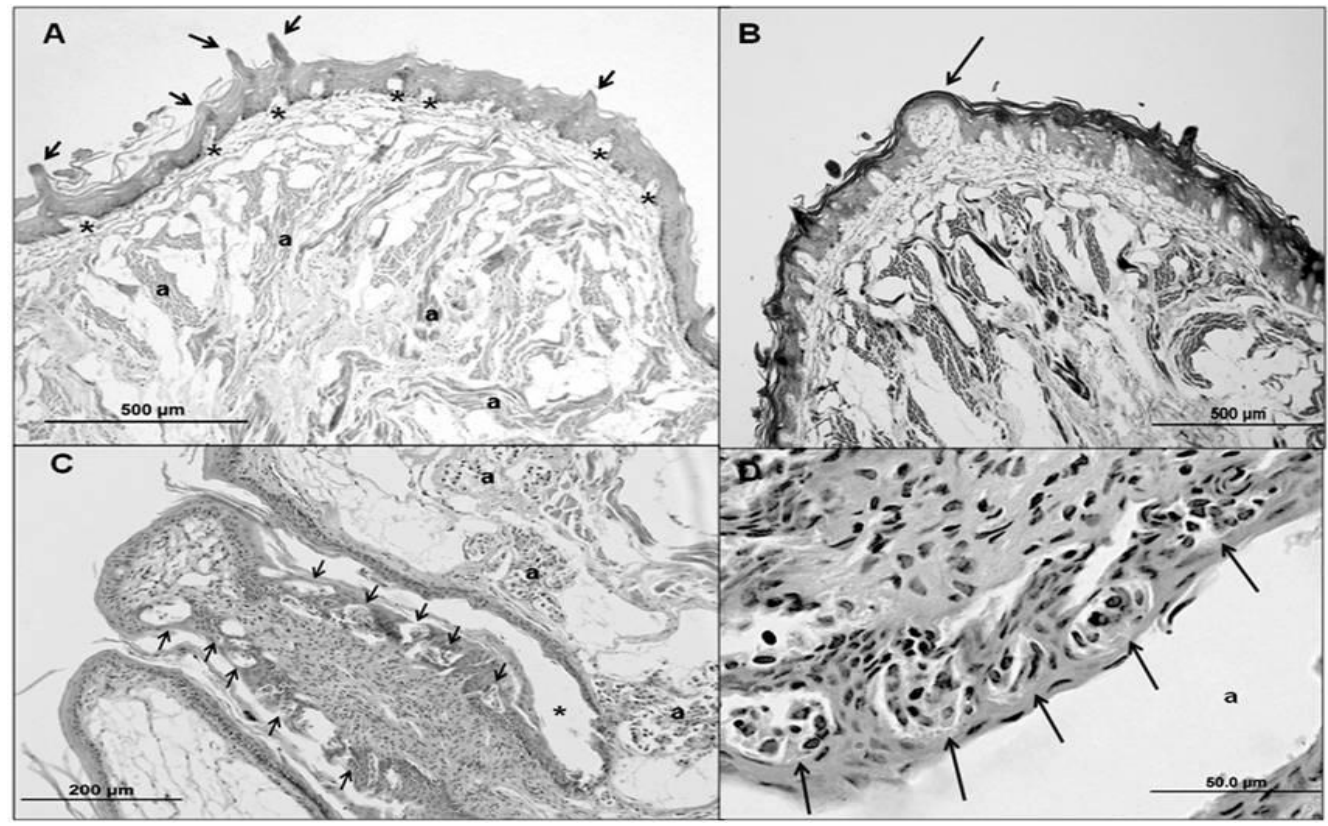

Figure 2. Photomicrography in the tongue of Bradypus variegatus - A - General aspect of the dorsal face; the presence of filiform papillae (arrows), connective tissue, conjunctive projections of different shapes (*) and sheaves of skeletal striated muscle fibers disposed in three levels (a) is observed. HE 10X coloration. B- Fungiform papilla (arrow) Masson's Tri-chrome_10X coloration C- Vallate papilla, gustatory corpuscules (arrows), ditches of the papilla (*), Von Ebner's glands (a). HE_20X coloration. D- Larger increase of several gustatory corpuscules (arrows) and the ditch of the papilla (a). HE_100X coloration.

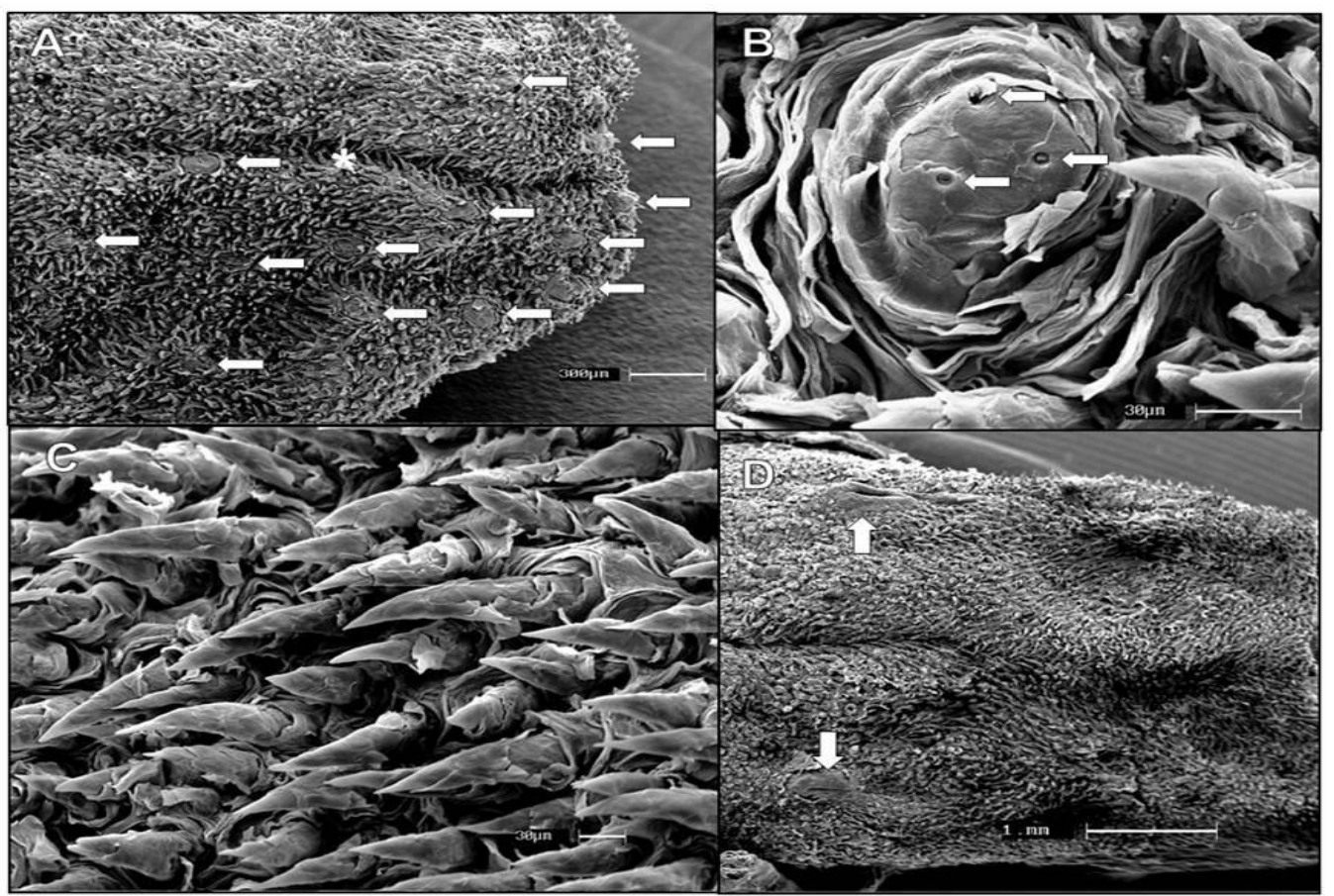

Figure 3. Scanning electron photomicrography in the tongue of Bradypus variegatus - A: General aspect of the rostral part of the tongue; the arrows show several fungiform papillae among the filiform ones, and * indicates the very evident sulcus in the rostral part of the tongue. B- Fungiform papilla, gustatory pores (white arrows). C Filiform papillae distributed along the dorsal surface of the tongue. D - The root of the tongue; the arrows evidence the location and the framework of vallate papillae, and the median sulcus among them. 
In our study with $B$. variegatus the presence of a median sulcus of the tongue was noted, which was extended from the tongue's root to the apex, disagreeing with findings by Benetti et al. (2009) after morphological post-evaluation of three-toed sloth (Bradypus torquatus), where the authors described the presence of a median sulcus of the tongue, restricted only to the rostral part of the tongue, as well as described by Jackowiak (2006) in the European mole and in deer by Adnyane et al. (2010).

The results obtained by light microscopy, through HE, PAS and Masson's Tri-chrome colorations, allowed to evidence the cell characteristics of the dorsal mucosa of the Bradypus variegate's tongue, which was coated with a keratinized stratified pavement epithelium. Similar structures were described in saru monkeys (Watanabe et al., 1992), camel (Erdunchaolu et al., 2001), Florida manatee (Levin and Pfeiffer, 2002), California sea lion (Yoshimura, 2002), three-toe sloth (Benetti et al., 2009) and squirrel monkey (Branco et al., 2011). Some animals reported by Guimarães (2006) presented non-keratinized stratified pavement epithelium different from the one found in this study.

In the dorsal face of the Bradypus variegatus' tongue, three different types of papillae were identified: filiform, fungiform and vallate, presenting distribution similar to other mammals, mainly as other Xenarthra species such as dwarf armadillo (Zaedyus pichiy) and three-toed sloth (Bradypus torquatus) (Ciuccio et al., 2008; Benetti, et al., 2009). However, the number of papillae was shown as variable, and there is a large amount of filiform papillae intermixed with few fungiform papillae on the dorsal face, and a larger concentration of fungiform papillae located on the rostral end of the tongue, besides the presence of two vallate papillae in the root of the tongue. Thus, it is confirmed that the dorsal face of the Bradypus variegatus' tongue presented numerous filiform papillae, similar to the ones reported by Morais and Watanabe (1988) on the armadillo tongue (Euphractus sexcinctus), Morais et al. (1994) on the ninebanded armadillo (Dasypus novemcinctus) and Benetti et al. (2009) on the three-toed sloth tongue (Bradypus torquatus).
The ventral face of the Bradypus variegatus' tongue, all over its extension, is smooth, not provided with any type of taste buds and papillae projections from its own lamina. Differently, Guimarães (2006) described the ventral surface of the tongue apex of cetaceans, evidencing filiform papillae, previously described in dromedaries by Qayyum et al. (1988).

Our results on the scanning electron microscope showed that filiform papillae were distributed all over the dorsal region of the tongue, but in a most dense way in the apex and body, being disposed around the fungiform papillae, as it was already reported by several authors (Morais et al., 1994; Watanabe et al., 1992; Jackowiak and Godynicki, 2004).

The standard of filiform papillae, comprising the whole dorsal surface of the tongue, with the growing number of branches for the medium third of the body, seems to be common in armadillos, observed in the species: Euphractus sexcinctus (Morais and Watanabe, 1988), Dasypus novemcintus (Morais et al., 1994), C. vellerosus (Estecondo et al., 2001), C. villosus (Estecondo et al., 2004) and Zaedyus pichiy (Ciuccio et al., 2008).

The disposition of filiform papillae, among the fungiform papillae, and the absence of gustatory pores indicates a mechanical function of protecting the mucous membrane of the tongue (Emura et al., 2000; Jackowiak, 2006). However, other authors suggest that these same papillae are related to the mastication process, once they increase the friction produced by the tongue during the movement and crushing of food (Pastor et al., 2008). Besides this they are also involved with the body cleaning function (Iwasaki et al., 1992) in some species.

Benetti et al. (2009) evaluating the three-toed sloth's tongue, described the presence of simple, bifurcated and trifurcated filiform papillae, similar to squirrel monkey (Branco et al., 2011), where the papillae are directed in the caudal orientation, different from our findings in $B$. variegatus, where the filiform papillae were from the simple type, in other words, with no bifurcations. Ciuccio et al. (2008) described in the armadillo, simple (conic) or branched filiform papillae, with some projections. 
Our results also showed that filiform papillae from brown-throat sloth tongue mucus membrane have a keratinized stratified scaly epithelium, and the papillae are directed to caudal orientation which characteristics were demonstrated by Ciuccio et al. (2008) in armadillo and Benetti et al. (2009) in three-toed sloth.

Observing the fungiform papillae regarding the location, Benetti et al. (2009) in Bradypus toquartu demonstrated that these are situated at the lateral margin of the tongue apex, similar to the species of our study, but on Bradypus variegatus, the fungiform papillae, besides being agglomerated on the tongue apex, are also located distributed in the dorsal surface of the tongue, as is reported in C. vellerosus armadillos (Estecondo et al., 2001), C. villosus (Estecondo et al., 2004) and Zaedyus pichiy (Ciuccio et al., 2008), besides other mammals, such as rodents, omnivorous and carnivorous (Jackowiak and Godynicki, 2004). In Saimiri sciureus (Branco et al., 2011) these papillae are distributed all over the tongue and there are no specific concentration points.

The fungiform papillae in brown-throated sloth present a practically smooth surface with irregular format, and in some areas, they present an oval or round shape, similar to the ones noted by Benetti et al. (2009) on the three-toed sloth. On the nine-banded armadillo (Dasypus novemcinctus) Morais et al. (1994) described the fungiform papillae with a dome shape.

On the surface of the fungiform papillae of Bradypus variegatus, the presence of several gustatory pores, similar to what is reported by Ciuccio et al. (2008) in Zaedyus pichiy, and Benetti (2009) in Bradypus torquatus tongues was observed.

According to Hwang and Lee (2007) the amount of gustatory pores present in the surface of fungiform papillae is proportional to the range of food that a species eats. The tip of the tongue can be considered a sensorial organ (Agungpriyono et al., 1995) and the probable cause for such fact is due to the big number of gustatory pores present in this region. In studies with other mammals, Jackowiak and Godynicki (2004) related the tip of the tongue with the preliminary analysis of the food tasting.

The vallate papillae in the present study were observed on the root region of the tongue, as is reported in other mammals (Qayyu et al., 1988; Pastor et al., 2008). Only two vallate papillae were observed in the distal third of Bradypus variegatus' tongue, corroborating with the results from Benetti et al. (2009) in Bradypus torquatus and agreeing with what was observed in other Xenarthras, such as armadillos (Morais and Watanabe, 1988; Morais et al., 1994; Estecondo et al., 2001; Estecondo et al., 2004; Ciuccio et al., 2008).

According to Benetti et al. (2009) in Bradypus torquatus, the gustatory corpuscules have round or elongated aspects, extending from the basal lamina up to the epithelial surface of the vallate papillae, similar to our results in Bradypus variegatus, where the gustatory pores were also located all over the vallate papilla's surface. This characteristic is different from the observed by Watanabe et al. (1992) and Agungpriyono et al. (1995) where they described that the gustatory pores are located in the lateral surface of the vallate papillae.

Several authors described the presence of taste buds on the vallate papillae (Emura et al., 1999, 2000; Yoshimura et al., 2002). However, Guimarães (2006), through light microscopy, did not observe taste buds in the vallate papillae of cetaceans.

Our results with the light and scanning electron microscope showed the absence of foliate papillae in Bradypus variegatus, the same reported for Bradypus torquatus (Benetti et al., 2009). The absence of foliate papillae has been considered a primitive characteristic, and a notable fact is that, although the Xenarthras belong to a primitive order of mammals (Kriegs et al., 2006), only the armadillo species (Euphractus sexcinctus) (Morais and Watanabe, 1988) has this papillae, and its absence is reported in the other species studied, such as Dasypus novemcictus (Morais et al., 1994), C. vellerosus and $C$. villosus (Estecondo et al., 2001; Estecondo et al., 2004), and Z. pichiy (Ciuccio et al., 2008). 


\section{ACKNOWLEDGEMENT}

$\mathrm{CNPq}$ for the financial support (Universal 14/2013).

\section{CONCLUSIONS}

The tongues from Bradypus variegatus presented gustatory papillae similar to the ones described for other Xenarthras species and wild mammals. The differences are related to type of food, habitat, and anatomical differentiation between species.

\section{REFERENCES}

ADNYANE, I.K.M.; ZUKI, A.B.; NOORDIN, M.M.; AGUNGPRIYONO, S. Morphological study of the lingual papillae in the barking deer, Muntiacus muntjak. Anat. Histol. Embryol., v.40, p.73-77, 2010.

AGUIAR, J.M. Species summaries and species discussions. In: FONSECA, G.; AGUIAR, J.; RYLANDS, A.; PAGLIA, A. et al. The 2004 Edentate Species Assessment Workshop. Edentata, 2004. p.3-26.

AGUNGPRIYONO, S.; YAMADA, J.; KITAMURA, N. et al. Morphology of the dorsal lingual papillae in the lesser mouse deer Tragulus javanicus. J. Anat., v.187, p.635-640, 1995.

BENETTI, E.J.; PICOLI, F.; GUIMARÃES, J.P. et al. Characteristics of filiform, fungiform and vallate papillae and surface of interface epithelium-connective tissue of the maned sloth tongue mucosa (Bradypus torquatus, illiger, 1811): light and scanning electron microscopy study. Anat. Histol. Embryol., v.38, p.42-48, 2009.

BRANCO, E.; GUIMARÃES, J.P.; MIGLINO, M.A. et al. Ultrastructural aspects of lingual papillae in squirrel monkey (Saimiri sciureus). Micros Res Techniq, v.74, p.484-487, 2011.

CARTElle C. Tempo Passado: Mamíferos do Pleistoceno em Minas Gerais. Belo Horizonte: Palco, 1994. 132p.

CHIARELLO, A.G.; CHIVERS, D.J.; BASSI, C. et al. A translocation experiment for the conservation of maned sloths, Bradypus torquatus (Xenarthra, Bradypodidae). Biol. Conserv., v.118, p.421-430, 2004.
CIUCCIO, M.; ESTECONDO, S.; CASANAVE, E.B. Scanning electron microscopy study of the dorsal surface of the tongue in Zaedyus pichiy (Mammalia, Xenarthra, Dasypodidae). Int. J. Morphol., v.26, p.13-18, 2008.

DORAN, G.A.; BAGGETT, H.A. Structural and Functional classification of mammalian tongues. J. Mammal., v.52, p.427-429, 1971.

EMURA, S.; TAMADA, A.; HAYAKAWA, D. et al. Morphology of the dorsal lingual papillae in the black rhinoceros (Diceros Bicornis). Anat. Histol. Embryol., v.29, p.371-374, 2000.

ERDUNCHAOLU, E.; TAKEHANA, K.; YAMAMOTO, E. et al. Characteristics of dorsal lingual papillae of the bactrian camel (Camelus bactrianus). Anat. Histol. Embryol., v.30, p.147$151,2001$.

ESTECONDO, S.; CODÓN, S.M.; CASANAVE, E.B. Scanning electron microscopy study of the dorsal surface of the tongue in Chaetophractus vellerosus (Mammalia, Dasypodidae). Rev. Chil. Anat., v.19, p.245-252, 2001.

ESTECONDO, S.; CODÓN, S.M.; CASANAVE, E.B. Scanning electron microscopic (SEM) study of the dorsal surface of the Chaetophractus villosus (Desmarest, 1804) (Mammalia, Dasypodidae) tongue. Physis. Secc.,v.59, p.136-137, 2004.

GUIMARÃES, J.P. Análise morfológica da superfície de interface epitélio - tecido conjuntivo da face dorsal da língua de cetáceos (ordem Cetacea subordem Odontoceti), empregando os métodos de microscopia de luz e eletrônica de varredura. 2006. 94f. Tese (Mestrado em Medicina Veterinária) - Faculdade de Medicina Veterinária e Zootecnia, Universidade de São Paulo, São Paulo.

HWANG, H.; LEE, J. Morphological study on the dorsal lingual papillae of Myotis macrodactylus. Korean J. Elect. Microsc., v.37, p.147-156, 2007.

IWASAKI, S.; YOSHIZAWA, H.; SUZUKI, K. Fine structure of the dorsal lingual epithelium of the japanese monkey Macaca fuscata fuscata. Acta Anat., v.144, p.267-277, 1992.

JACKOWIAK, H. Scanning electron microscopy study of the lingual papillae in the European mole (Talpa europea, L., Talpidae). Anat. Histol. Embryol., v.35, p.190-195, 2006. 
JACKOWIAK, H.; GODYNICKI, S. The scanning electron microscopic study of lingual papillae in the silver fox (Vulpes vulpes fulva, Desmarest, 1820). Ann. Anat., v.186, p.179-183, 2004.

KRIEGS, J.O.; CHURAKOV, G.; KIEFMANN, M. et al. Retroposed elements as archives for the evolutionary history of placental mammals. Plos Biol., v.4, p.537-44, 2006.

LEVIN, M.J.; PFEIFFER, C.J. Gross and microscopic observations on the lingual structure of the florida manatee Trichechus manatus latirostris. Anat. Histol. Embryol., v.31, p.278$285,2002$.

MORAIS, J.O.R.; WATANABE, I. Observações morfológicas das papilas linguais do tatu peba (Euphractus sexcinctus). Estudo aos microscópios óptico e eletrônico de varredura. Rev. Bras. Cien. Morfol., v.5, p.89-97, 1988.

MORAIS, J.R.I.J.; WATANABE, I.; KÖNIG Jr., B. Scanning electron microscopy of the lingual mucosa of the nine-banded armadillo Dasypus novemcinctus. An. Anat., v.176, p.357-361, 1994.

OKADA, S.; SCHRAUFNAGEL, D.E. Scanning electron microscopic structure of the lingual papillae of the common opossum (Didelphis marsupialis). Microsc. Res. Techniq., v.11, p.319-32, 2005.
PASTOR, J.F.; BARBOSA, M.; PAZ, F.J. Morphological study of the lingual papillae of the giant panda (Ailuropoda melanoleuca) by scanning electron microscopy. J. Anat., v.212, p.99-105, 2008.

QAYYUM, M.A.; FATANI, J.A.; MOHAJIR, A.M. Scanning electron microscopic study of the lingual papillae of the one humped camel, Camelus dromedarius. J. Anat., v.160, p.21-26, 1988.

QUEIROZ, H.L. Preguiças e Guaribas, os mamíferos folívoros arborícolas do Mamirauá. v.2. Rio de Janeiro: CNPq e Sociedade Civil Mamirauá, 1995. 176p.

WATANABE, I.; INOKUCHI, T.; YAMADA, E.; SEMPRINI, M. Distribution of the taste buds on the lingual mucosa Of The Macaca Fuscata. Scanning Electron Microscopy Study. Rev. Bras. Cien. Morfol., v.9, p.7-13, 1992.

WETZEL, R.M.; KOCK, D. The identity of the Bradypus variegatus Schinz, 1985 (Mammalia: Edentata). Pro. Biol Soc., v.86, p.25-34, 1973.

YOSHIMURA, K.; SHINDOH, J.; KOBAYASHI, K. Scanning electron microscopy study of the tongue and lingual papillae of the California sea lion (Zalophus californianus californianus). Anat. Rec., v.267, p.146-153, 2002. 